\title{
DISTRIBUSI PENDERITA ABSES SUBMANDIBULA DI BAGIAN T.H.T.K.L RSUD BANGLI BALI PERIODE JANUARI 2016 SAMPAI DESEMBER 2018
}

\author{
I Gusti Ayu Oka Sri Utari \\ Fakultas Kedokteran Universitas Islam Al-Azhar \\ Rumah Sakit Umum Daerah Bangli - Bali
}

\begin{abstract}
ABSTRAK
Abses submandibula menempati urutan tertinggi dari seluruh abses leher dalam. Faktor predisposisinya adalah higiene orodental yang buruk, diabetes melitus serta adanya penyakit imunodefisiensi. Angka morbiditas dari komplikasi yang ditimbulkan akibat abses submandibula masih cukup tinggi sehingga pengetahuan tentang faktor predisposisi serta diagnosis dan penanganan yang cepat dan tepat sangat dibutuhkan. Tujuan penelitian ini adalah untuk mengetahui distribusi penderita abses submandibula di bagian T.H.T.K.L RSUD Bangli Bali dalam 3 tahun terakhir yaitu bulan Januari 2016 sampai Desember 2018. Penelitian ini merupakan studi deskriptif retrospektif dengan sampel adalah seluruh penderita abses submandibula di bagian T.H.T.K.L RSUD Bangli dalam 3 tahun terakhir yaitu pada bulan Januari 2016 sampai Desember 2018 yang memenuhi kriteria inklusi. Pada hasil penelitian didapatkan jumlah penderita yang memenuhi kriteria inklusi adalah sebanyak 28 orang dengan umur penderita rata-rata 42,32 tahun, laki-laki lebih banyak dari perempuan yaitu $60,71 \%$, keluhan penderita terbanyak pembengkakan di bawah rahang dan nyeri yaitu $100 \%$ dan $92,86 \%$, sebagian besar unilateral yaitu $96,43 \%$, sumber infeksinya adalah sebanyak $100 \%$ dari infeksi gigi, kuman terbanyak adalah Streptokokus viridians yaitu sebanyak $39,29 \%$, sebanyak $85,71 \%$ penderita sensitif terhadap antibiotik sefalotin dan meropenem, komplikasi didapatkan pada 2 pasien yaitu abses parotis dan lama perawatan pasien terbanyak adalah 5 hari yaitu $42,87 \%$. Disimpulkan bahwa sumber infeksi penderita abses submandibula pada penelitian ini adalah dari infeksi gigi, kuman terbanyak adalah Streptokokus viridians, sebagian besar penderitasensitif terhadap antibiotik sefalotin dan meropenem, serta komplikasi yang didapatkan pada penderita adalah abses parotis.
\end{abstract}

Kata Kunci : Abses Submandibula, Distribusi, RSUD Bangli.

\section{PENDAHULUAN}

Pada umumnya sumber infeksi pada ruang submandibula berasal dari proses infeksi gigi, dasar mulut, faring, kelenjar limfe submandibula, trauma serta kelanjutan infeksi dari ruang leher dalam lainnya. Sebagian besar abses submandibula disebabkan oleh infeksi gigi yaitu sebanyak $70-85 \% .^{1-3,5}$

Penyakit malaria merupakan infeksi yang disebabkan oleh parasit malaria, suatu protozoa darah genus plasmodium yang ditularkan oleh nyamuk anopheles betina yang terinfeksi. Manusia yang terjangkit malaria akan mengalami gejala demam tinggi, disertai fase menggigil dan fase berkeringat. Malaria juga dapat menyebabkan nyeri kepala, rasa lemas Abses submandibula menempati urutan tertinggi dari seluruh abses leher dalam. ${ }^{1,2,4}$ Beberapa penelitian mendapatkan angka kejadiannya lebih banyak pada laki-laki daripada perempuan., ${ }^{4,67}$ Faktor predisposisinya adalah higiene orodental yang buruk, diabetes melitus serta adanya penyakit imunodefisiensi. ${ }^{2,3,7}$ Penatalaksanaan abses submandibula meliputi insisi drainase abses yang optimal serta pemberian antibiotik yang adekuat. ${ }^{3,8,9}$ 
Angka kejadian abses submandibula sudah semakin menurun, hal ini disebabkan penggunaan antibiotik yang luas serta kesehatan mulut yang meningkat namun angka morbiditas dari komplikasi yang ditimbulkan akibat abses submandibula masih cukup tinggi sehingga diagnosis dan penanganan yang cepat dan tepat sangat dibutuhkan. ${ }^{1-3,7}$ Dengan demikian kami melakukan penelitian deskriptif untuk mengetahui distribusi penderita abses submandibula di bagian T.H.T.K.L RSUD Bangli Bali dalam 3 tahun terakhir yaitu bulan Januari 2016 sampai Desember 2018 sehingga diharapkan hasil penelitian ini dapat digunakan dalam upaya pencegahan maupun penatalaksanaan abses submandibula secara lebih cepat dan tepat khususnya di RSUB Bangli Bali sehingga komplikasi yang dapat berakibat fatal dapat dihindari.

Ruang submandibula terdiri dari ruang sublingual dan submaksila yang dipisahkan oleh otot milohyoid. Ruang submaksila dibagi lagi menjadi ruang submental dan submaksila oleh otot digastrikus $\quad$ anterior. $^{10} \quad$ Ruang submandibula terletak pada dasar mulut dan lapisan superfisial dari bagian bawah fasia servikal dalam. Tulang hyoid merupakan batas pada sisi inferior dan mandibula membentuk batas anterior. Pada bagian anterior otot milohyoid dan bagian anterior muskulus digastrikus melekat pada ruang submandibula dengan bagian posterior ligamentum digastrikus dan stilomandibula berfungsi sebagai batas posteriornya. Hioglosus, milohyoid, stiloglosus, genioglosus dan otot geniohyoid pada bagian medial dengan platisma dan mandibula menjadi bagian lateral. Ruang ini tidak sepenuhnya dipisahkan oleh diafragma otot milohyoid, ruang sublingual berada di atasnya sementara ruang submaksila dan submental berada di bawahnya.

Ruang submaksila dan submental dipisahkan oleh bagian anterior otot digastrikus tetapi kedua ruang tersebut masih dapat berhubungan satu sama lain. Kelenjar ludah submandibula dan sublingual melekat pada sekitar tepi posterior dari otot milohyoid sehingga kelenjar ludah tersebut menempati ruang submandibula dan sublingual. Oleh karena itu, infeksi yang dimulai di ruang sublingual dapat menyebar ke ruang submandibula dan sebaliknya. ${ }^{3,10,11}$

Infeksi pada abses submandibula dapat disebabkan oleh bakteri aerob, anaerob ataupun campuran. Organisme penyebab yang paling umum ditemukan dari hasil kultur adalah Streptokokus viridians, Stafilokokus epidermidis, Stafilokokus aureus, Streptokokus $\beta$ hemolitikus, bacteroides, fusobacterium, spesies Peptostreptokokus, neisseria, Klebsiella pneumoniae dan pseudomonas. ${ }^{3,7,14} \quad$ Pada abses 
submandibula yang bersumber dari infeksi gigi, bakteri yang paling sering ditemukan adalah grup Streptokokus dan bakteri anaerob. ${ }^{12,15,16}$ Jenis streptokokus yang paling sering ditemukan pada penderita abses submandibula yang disebabkan oleh infeksi gigi adalah Streptokokus viridians sedangkan pada abses submandibula yang tidak disebabkan oleh infeksi gigi, kuman yang paling sering ditemukan adalah Stafilokokus aureus. ${ }^{3,7} \quad$ Klebsiella pneumoniae merupakan bakteri aerob gram negatif yang paling banyak ditemukan pada pasien diabetes melitus. ${ }^{14}$ Bakteri anaerob sulit tumbuh dalam kultur sehingga diduga bahwa prevalensi bakteri anaerob pada abses leher dalam yang sesungguhnya lebih tinggi daripada yang dilaporkan pada kepustakaan. Adanya bakteri anaerob dapat diperkirakan bila ditemukan pus yang berbau busuk. ${ }^{16,17}$

Angka kejadiannya abses submandibula lebih banyak ditemukan pada laki-laki dibanding perempuan dengan perbandingan 3:2. Kekerapan abses submandibula adalah $13,5 \%$ $60 \% .^{6}$ Huang dkk. ${ }^{6}$ dalam penelitiannya pada tahun 1997 sampai 2002, menemukan kasus infeksi leher dalam sebanyak 185 kasus. Abses submandibula $15,7 \%$ merupakan kasus terbanyak kedua setelah abses parafaring $38,4 \%$, diikuti oleh angina Ludovici
$12,4 \%$, parotis $7 \%$ dan retrofaring $5,9 \% .^{2}$ Bakteri yang masuk kedalam jaringan yang sehat dapat menyebabkan terjadinya infeksi. Sebagian sel mati dan hancur, meninggalkan rongga yang berisi jaringan dan se-sel yang terinfeksi. Sel-sel darah putih yang merupakan pertahanan tubuh dalam melawan infeksi, bergerak kedalam rongga tersebut dan setelah menelan bakteri maka sel darah putih akan mati. Sel darah putih yang mati inilah yang membentuk pus dan mengisi rongga tersebut. Adanya penimbunan pus ini menyebabkan jaringan disekitarnya akan terdorong dan tumbuh di sekeliling abses menjadi dinding pembatas. ${ }^{17,18}$

Infeksi ruang leher dalam dapat terjadi melalui beberapa cara yaitu limfogen, hematogen, perkontinuitatum dan infeksi langsung. Beratnya infeksi tergantung dari virulensi kuman, daya tahan tubuh dan lokasi anatomi. Ruang submandibula terletak diantara otot dan kulit milohyoid yang memiliki batas posterior yang terbuka sehingga berhubungan dengan ruang di dekatnya. Saat ruang submandibula mengalami infeksi, pembengkakan dimulai pada batas inferior lateral dari mandibula dan meluas ke medial menuju area digastrikus dan ke posterior menuju tulang hyoid. ${ }^{1,18}$

Beberapa penelitian melaporkan bahwa infeksi gigi atau odontogenik merupakan penyebab terbanyak dari abses submandibula. Infeksi gigi dapat 
mengenai pulpa dan periodontal. Penyebaran infeksi dapat meluas melalui foramen apikal gigi ke daerah sekitarnya. Pada infeksi odontogenik perkembangan infeksi dapat terjadi antara satu hari sampai tiga minggu. ${ }^{5,12,19}$

Infeksi dari submandibula dapat meluas ke ruang mastikator kemudian ke parafaring. Perluasan infeksi ke parafaring juga dapat langsung dari ruang submandibula. Selanjutnya infeksi dapat menjalar ke daerah potensial lainnya., 72

\section{METODE}

Data diambil dari catatan medis semua pasien abses submandibula di bagian T.H.T.K.L RSUD Bangli Bali selama 3 tahun terakhir yaitu dari Januari 2016 sampai Desember 2018. Data yang diperoleh kemudian ditabulasi dan dipaparkan secara deskriptif dalam bentuk tabel dan narasi. Sampel penelitian adalah seluruh penderita abses submandibula di bagian T.H.T.K.L RSUD Bangli dalam 3 tahun terakhir yaitu pada bulan Januari 2016 sampai Desember 2018 yang telah terdiagnosis mengalami abses mandibular dan telah dilakukan kultur pus dan uji sensitifitas antibiotic.

\section{HASIL PENELITIAN}

Berdasarkan penelitian yang dilakukan di bagian T.H.T.K.L RSUD Bangli Bali terhadap penderita abses submandibula selama 3 tahun terakhir dari Januari 2016 sampai Desember 2018 didapatkan hasil yaitu penderita yang memenuhi kriteria inklusi adalah sebanyak 28 orang.

Tabel 01. Distribusi penderita abses submandibula berdasarkan umur.

\begin{tabular}{|c|c|c|}
\hline Umur & $\mathbf{N}$ & $\mathbf{\%}$ \\
\hline $10-19$ & 1 & 3,57 \\
\hline $20-29$ & 4 & 14,29 \\
\hline $30-39$ & 6 & 21,43 \\
\hline $40-49$ & 10 & 35,71 \\
\hline $50-59$ & 4 & 14,29 \\
\hline $60-69$ & 2 & 7,14 \\
\hline $70-79$ & 1 & 3,57 \\
\hline Total & 28 & 100 \\
\hline
\end{tabular}

Berdasarkan Tabel 01 didapatkan penderita abses submandibula terbanyak terdapat pada kelompok umur 40-49 tahun yaitu sebanyak 10 orang atau $35,71 \%$. Penderita dengan umur termuda adalah 10 tahun dan umur tertua adalah 74 tahun. Rata-rata umur penderita adalah 42,32 tahun.

Tabel 02. Distribusi penderita abses submandibula berdasarkan jenis kelamin.

\begin{tabular}{|c|c|c|}
\hline Jenis Kelamin & $\mathbf{N}$ & \% \\
\hline Laki-laki & 17 & 60,71 \\
\hline Perempuan & 11 & 39,29 \\
\hline Total & 28 & 100 \\
\hline
\end{tabular}

Berdasarkan Tabel 02 didapatkan penderita abses submandibula adalah sebanyak 28 orang dengan kebanyakan penderita adalah laki-laki yaitu 17 orang atau sebesar $60,71 \%$ dan sisanya perempuan yaitu sebanyak 11 orang atau sebesar 39,29\%. 
Tabel 03. Distribusi penderita abses submandibula berdasarkan keluhan.

\begin{tabular}{|l|c|c|}
\hline \multicolumn{1}{|c|}{ Keluhan } & N = 28 & \% \\
\hline $\begin{array}{l}\text { Pembengkakan di } \\
\text { bawah rahang }\end{array}$ & 28 & 100 \\
\hline Nyeri membuka & 17 & 60,71 \\
\hline $\begin{array}{l}\text { Sulit } \\
\text { mulut }\end{array}$ & 18 & 64,29 \\
\hline Demam &
\end{tabular}

Keterangan : $\mathrm{N}$ adalah jumlah subjek penelitian dengan satu penderita dapat mengalami satu atau lebih gejala di atas.

Berdasarkan Tabel 03 didapatkan sebanyak 28 orang atau $100 \%$ penderita abses submandibula datang dengan keluhan pembengkakan di bawah rahang, penderita yang mengeluh nyeri di daerah pembengkakan sebanyak 26 orang atau $92,86 \%$, penderita yang mengeluh sulit membuka mulut sebanyak 17 orang atau $60,71 \%$ dan penderita yang mengeluh demam adalah sebanyak 18 orang atau $64,29 \%$.

Tabel 04. Distribusi penderita abses submandibula berdasarkan lokasi.

\begin{tabular}{|c|c|c|}
\hline Lokasi & $\mathbf{N}$ & $\mathbf{\%}$ \\
\hline Unilateral & 27 & 96,43 \\
\hline Bilateral & 1 & 3,57 \\
\hline Total & 26 & 100 \\
\hline
\end{tabular}

Berdasarkan Tabel 04 didapatkan sebagian besar penderita abses submandibula adalah unilateral yaitu sebanyak 27 orang atau 96,43\% sedangkan penderita abses submandibula bilateral hanya 1 orang atau $3,57 \%$.

Tabel 05. Distribusi penderita abses submandibula berdasarkan sumber infeksi.

\begin{tabular}{|c|c|c|}
\hline $\begin{array}{c}\text { Sumber } \\
\text { infeksi }\end{array}$ & $\mathbf{N}$ & $\mathbf{\%}$ \\
\hline Gigi & 28 & 100 \\
\hline $\begin{array}{c}\text { Sumber } \\
\text { infeksi lainnya }\end{array}$ & 0 & 0 \\
\hline Total & 26 & 100 \\
\hline
\end{tabular}

Berdasarkan Tabel 05 didapatkan hasil bahwa sumber infeksi dari penderita abses submandibula pada penelitian ini semuanya berasal dari gigi yaitu sebanyak $100 \%$.

Tabel 06. Distribusi penderita abses submandibula berdasarkan kultur kuman.

\begin{tabular}{|l|c|c|}
\hline \multicolumn{1}{|c|}{ Kultur Kuman } & N & \% \\
\hline $\begin{array}{l}\text { Streptokokus } \\
\text { viridians }\end{array}$ & 11 & 39,29 \\
\hline $\begin{array}{l}\text { Streptokokus } \\
\text { pirogens }\end{array}$ & 1 & 3,57 \\
\hline Streptokokus $\beta$ & 2 & 7,14 \\
\hline Streptokokus $\alpha$ & 2 & 7,14 \\
\hline $\begin{array}{l}\text { Klebsiella } \\
\text { pneumoniae }\end{array}$ & 2 & 7,14 \\
\hline $\begin{array}{l}\text { Spesies } \\
\text { Enterokokus }\end{array}$ & 1 & 3,57 \\
\hline $\begin{array}{l}\text { Tidak ada } \\
\text { pertumbuhan } \\
\text { kuman }\end{array}$ & 9 & 32,15 \\
\hline \multicolumn{1}{|c|}{ Total } & 28 & 100 \\
\hline
\end{tabular}

Berdasarkan Tabel 06 didapatkan jenis kuman yang terbanyak ditemukan pada hasil kultur kuman adalah Streptokokus viridans pada 11 penderita atau 39,29\% sedangkan Klebsiella pneumoniae didapatkan pada 2 penderita atau 7,14\%. Pada 9 penderita atau 32,15 $\%$ tidak ditemukan pertumbuhan kuman. 
Tabel 07. Distribusi penderita abses submandibula berdasarkan sensitivitas antibiotik terhadap kuman.

\begin{tabular}{|l|c|c|}
\hline Nama Antibiotik & $\mathbf{N = 2 8}$ & $\mathbf{\%}$ \\
\hline Ampisilin & 7 & 25 \\
\hline $\begin{array}{l}\text { Amoksisilin/asam } \\
\text { klavulanat }\end{array}$ & 9 & 32,14 \\
\hline Sefalotin & 24 & 85,71 \\
\hline Sefotaksim & 20 & 71,43 \\
\hline Sefepim & 21 & 75 \\
\hline Imipenem & 18 & 64,29 \\
\hline Meropenem & 24 & 85,71 \\
\hline Vankomisin & 14 & 50 \\
\hline Eritromisin & 12 & 42,86 \\
\hline Tetrasiklin & 8 & 28,57 \\
\hline Klindamisin & 15 & 53,57 \\
\hline Linezolid & 21 & 75 \\
\hline Kloramfenikol & 6 & 21,43 \\
\hline Amikasin & 9 & 32,14 \\
\hline Gentamisin & 9 & 32,14 \\
\hline Siprofloksasin & 13 & 46,43 \\
\hline Levofloksasin & 17 & 60,71 \\
\hline
\end{tabular}

Keterangan : $\mathrm{N}$ adalah jumlah subjek penelitian dengan satu penderita dapat sensitif terhadap lebih dari satu antibiotik di atas.

Berdasarkan Tabel 07 didapatkan sebanyak 85,71 \% penderita abses submandibula sensitif terhadap antibiotik sefalotin dan meropenem dan hanya 25 $\%$ sensitif terhadap ampisilin.

Tabel 08. Distribusi penderita abses submandibula berdasarkan komplikasi.

\begin{tabular}{|c|c|c|}
\hline Komplikasi & N & $\%$ \\
\hline Abses parotis & 2 & 7,14 \\
\hline $\begin{array}{c}\text { Tidak ada } \\
\text { komplikasi }\end{array}$ & 26 & 92,86 \\
\hline Total & 28 & 100 \\
\hline
\end{tabular}

Berdasarkan Tabel 08 didapatkan hasil penderita abses submandibula pada penelitian ini mendapatkan komplikasi abses parotis sebanyak 2 orang atau $7,14 \%$ dan sisanya tidak ada komplikasi sebanyak 26 orang atau $92,86 \%$.
Tabel 09. Distribusi penderita abses submandibula berdasarkan lama perawatan.

\begin{tabular}{|c|c|c|}
\hline $\begin{array}{c}\text { Lama perawatan } \\
\text { ( Hari) }\end{array}$ & $\mathbf{N}$ & $\mathbf{\%}$ \\
\hline 4 & 3 & 10,71 \\
\hline 5 & 12 & 42,87 \\
\hline 7 & 6 & 21,43 \\
\hline 8 & 3 & 10,71 \\
\hline 10 & 2 & 7,14 \\
\hline 14 & 1 & 3,57 \\
\hline 17 & 1 & 3,57 \\
\hline Total & 28 & 100 \\
\hline
\end{tabular}

Berdasarkan Tabel 09 didapatkan lama perawatan penderita abses submandibula di bagian T.H.T.K.L RSUD Bangli periode Januari 2016 sampai Desember 2018 sebagian besar 5 hari yaitu sebanyak 12 orang atau $42,87 \%$.

\section{PEMBAHASAN}

Abses submandibula dapat terjadi pada semua umur. Pada penelitian yang dilakukan oleh Huang dkk. ${ }^{6}$ terhadap 185 kasus abses submandibula didapatkan $52,4 \%$ penderita abses leher dalam berumur diatas 50 tahun sedangkan Parhiscar dkk. ${ }^{16}$ menyebutkan bahwa sebanyak 50\% kasus abses leher dalam terjadi pada usia dekade ketiga sampai keempat. Pada penelitian ini didapatkan penderita abses submandibula terbanyak terdapat pada kelompok umur 40-49 tahun yaitu sebanyak 10 orang atau $35,71 \%$. Penderita dengan umur termuda adalah 10 tahun dan umur tertua adalah 74 tahun. Rata - Rata umur penderita 
adalah 42,32 tahun.

Huang dkk. ${ }^{6}$ mendapatkan kasus abses submandibula tersering terjadi pada laki-laki daripada perempuan dengan perbandingan 3:2. Pada penelitian yang dilakukan oleh Rizzo dkk. ${ }^{7}$ terhadap 210 abses submandibula didapatkan penderita laki-laki sebanyak 51,9\% dan perempuan sebanyak 48,1\%. Pada penelitian ini didapatkan penderita abses submandibula adalah sebanyak 28 orang dengan lebih banyak penderita adalah laki-laki yaitu 17 orang atau sebesar $60,71 \%$ dan sisanya perempuan yaitu sebanyak 11 orang atau sebesar 39,29\%.

Pasien dengan abses submandibula sering datang dengan keluhan bengkak di bawah rahang pada satu atau kedua sisi yang dirasakan nyeri. Pasien juga mengeluh demam disertai dengan keluhan lainnya seperti nyeri menelan serta sulit membuka mulut. ${ }^{3,7,19,20}$ Rana dkk. ${ }^{2}$ menyatakan bahwa gejala berupa bengkak dan nyeri merupakan keluhan utama sebagian besar dari penderita abses leher dalam. Hal ini didukung oleh penelitiannya terhadap 50 pasien abses leher dalam yang mendapatkan sebanyak $96 \%$ pasien mengeluh adanya pembengkakan, sebanyak $92 \%$ pasien mengeluh nyeri dan $66 \%$ pasien mengeluh demam. Rizzo dkk. ${ }^{7}$ pada penelitiannya mendapatkan 98,8\% penderita abses submandibula mengeluh adanya pembengkakan, $23,5 \%$ penderita mengeluh demam, 24,7\% mengeluh nyeri dan $17,3 \%$ penderita mengeluh adanya trismus. Pada penelitian ini didapatkan sebanyak $100 \%$ penderita abses submandibula datang dengan keluhan pembengkakan di bawah rahang, penderita yang mengeluh nyeri di daerah pembengkakan sebanyak $92,86 \%$, penderita yang mengeluh trismus sebanyak $60,71 \%$ dan penderita yang mengeluh demam sebanyak $64,29 \%$.

Rizzo dkk. ${ }^{7}$ mendapatkan sebanyak $81,5 \%$ pasien abses submandibula unilateral dan $18,5 \%$ bilateral. Penderita abses submandibula di bagian T.H.T.K.L RSUD Bangli pada bulan Januari 2016 sampai Desember 2018 sebagian besar unilateral yaitu sebanyak 27 orang atau $96,43 \%$ dan hanya 1 orang atau $3,57 \%$ penderita abses submandibula bilateral.

Infeksi gigi atau odontogenik merupakan penyebab terbanyak dari abses submandibula. Infeksi gigi dapat mengenai pulpa dan periodontal. Penyebaran infeksi dapat meluas melalui foramen apikal gigi ke daerah sekitarnya. Pada penelitian yang dilakukan oleh Rizzo dkk. ${ }^{7}$ didapatkan sebanyak 46,9\% abses submandibula adalah odontogenik. Rana dkk. ${ }^{2}$ mendapatkan bahwa infeksi odontogenik merupakan penyebab dari 48\% abses leher dalam sedangkan pada penelitian yang dilakukan oleh Parhiscar dkk. $^{16}$ didapatkan sebanyak $43 \%$ penyebab abses leher dalam adalah 
odontogenik. Penderita abses submandibula di bagian T.H.T.K.L RSUD Bangli pada bulan Januari 2016 sampai Desember 2018 sebanyak 100\% adalah odontogenik.

Pada abses submandibula yang bersumber dari infeksi gigi, bakteri yang paling sering ditemukan adalah grup Streptokokus dan bakteri anaerob. ${ }^{12,15,16}$ Jenis streptokokus yang paling sering ditemukan pada penderita abses submandibula adalah Streptokokus viridans sedangkan pada abses submandibula yang tidak disebabkan oleh infeksi gigi, kuman yang paling sering ditemukan adalah Stafilokokus aureus. ${ }^{3,7}$ Klebsiella pneumoniae merupakan bakteri aerob gram negatif yang paling banyak ditemukan pada pasien diabetes melitus. ${ }^{14}$ Lee dkk. ${ }^{14}$ melaporkan hasil kultur pada penderita abses leher dalam adalah $83,3 \%$ positif untuk kuman aerob dan $31,3 \%$ untuk kuman anaerob. Mazita dkk. ${ }^{17}$ pada penelitiannya melaporkan mayoritas hasil kultur pada penderita abses leher dalam adalah tidak ditemukan pertumbuhan kuman. Parhiscar dkk. ${ }^{16}$ menyatakan bahwa hasil kultur dari 39\% abses leher dalam adalah Streptokokus viridans. Gadre dkk. ${ }^{3}$ menyatakan bahwa jenis Streptokokus yang paling sering ditemukan pada penderita abses submandibula adalah Streptokokus viridians dan pada penelitian yang dilakukan oleh Rizzo dkk. ${ }^{7}$ didapatkan
Streptokokus viridians ditemukan pada $23,8 \%$ penderita abses submandibula. Pada penelitian ini didapatkan jenis kuman yang terbanyak ditemukan pada hasil kultur kuman adalah Streptokokus viridans yaitu pada 11 penderita atau $39,29 \%$ dan pada 9 penderita atau $32,15 \%$ tidak ditemukan pertumbuhan kuman. Berdasarkan hasil pemeriksaan sensitivitas antibiotik didapatkan sebanyak $85,71 \%$ penderita abses submandibula sensitif terhadap antibiotik sefalotin dan meropenem dan hanya $25 \%$ sensitif terhadap ampisilin.

Perawatan penderita dengan abses Submandibula di bagian T.H.T.K.L RSUD Bangli Bali periode Januari 2016 sampai Desember 2018 adalah rawat inap dengan lama perawatan sebagian besar 5 hari yaitu sebanyak 12 orang atau 42,87\%. Pada penderita dilakukannya insisi dan drainase abses dan diberikan antibiotik intravena untuk kuman aerob dan anaerob. Pilihan antibiotika ini kemudian disesuaikan dengan bakteri penyebabnya yang didasarkan atas hasil kultur dan uji sensitivitas terhadap antibiotika.

Komplikasi yang dapat terjadi pada penderita abses submandibula adalah obstruksi jalan nafas, osteomielitis mandibula, penyebaran infeksi ke ruang leher dalam di dekatnya, mediastinitis serta sepsis. ${ }^{7,12,21}$ Rizzo dkk. $^{7}$ menyatakan bahwa terdapat keterlibatan 
ruang leher dalam yang lain pada $29,6 \%$ pasien abses submandibula. Fragiskos dkk. ${ }^{12}$ menyatakan bahwa abses parotis dapat timbul sebagai komplikasi dari abses submandibula. Penderita abses submandibula pada penelitian ini mendapatkan komplikasi abses parotis sebanyak 2 orang atau 7,14\% dan sisanya tidak ada komplikasi sebanyak 26 orang atau $92,86 \%$.

\section{SIMPULAN}

Penelitian ini merupakan penelitian deskriptif retrospektif untuk mengetahui distribusi penderita abses submandibula di bagian T.H.T.K.L RSUD Bangli Bali periode Januari 2016 sampai Desember 2018 dengan hasil penelitian didapatkan penderita abses submandibula sebanyak 28 orang terbanyak terdapat pada kelompok umur 40-49 tahun yaitu $35,71 \%$ dan penderita laki-laki lebih banyak dari perempuan.

Penderita datang dengan keluhan pembengkakan di bawah rahang, nyeri di daerah pembengkakan, sulit membuka mulut dan demam. Keluhan penderita terbanyak adalah pembengkakan di bawah rahang dan nyeri yaitu sebanyak $100 \%$ dan 92,86. Sebagian besar penderita abses submandibula adalah unilateral yaitu sebanyak 27 orang atau $96,43 \%$ dan sumber infeksi dari penderita abses submandibula pada penelitian ini semuanya berasal dari gigi yaitu sebanyak 100\%. Penderita paling banyak sensitif terhadap antibotik sefalotin dan meropenem yaitu $85,71 \%$ dan hasil kultur terbanyak adalah Streptokokus viridians. Lama perawatan penderita abses submandibula di bagian T.H.T.K.L RSUD Bangli Bali periode Januari 2016 sampai Desember 2018 bervariasi dengan sebagian besar penderita dirawat selama 5 hari yaitu sebanyak 42,87\%. Penderita abses submandibula pada penelitian ini yang mendapatkan komplikasi adalah sebanyak 2 orang atau $7,14 \%$ yaitu abses parotis.

\section{DAFTAR PUSTAKA}

Oliver ER, Gillespie MB. Deep Neck Space Infections. In: Flint PW, Haughey BH, Lund VJ, Niparko JK, Richardson MA, Robbins KT, et al., editors. Cummings Otolaryngology Head and Neck Surgery. 5th ed. Philadelphia: Mosby, Inc.; 2010. p. 201-8.

Rana K, Rathore PK, Wadhwa V, Kumar SS. Deep Neck Infections: Continuing Burden in Developing World. International Journal of Phonosurgery and Laryngology. 2013;3(1):6- 9.

Gadre AK, Gadre KC. Infections of the Deep Spaces of the Neck. In: Bailey BJ, Johnson JT, Newlands SD, editors. Head \& Neck Surgery - Otolaryngology. 4th ed. Philadelphia : Lippincott Williams \& Wilkins; 2006. p. 666-82.

Eric R, Gilespie MB, Deep neck space infection. In : Paaul WF, Valerie JL, editors. Cumming Otolaryngology Head and Neck Surgery. $5^{\text {th }}$ edition. Philadelpia : Elsevier, 2010.p.631-52. 
Christian JM. Odontogenic Infections. In: Flint PW, Haughey BH, Lund VJ, Niparko JK, Richardson MA, Robbins KT, et al., editors. Cummings Otolaryngology Head and Neck Surgery. Philadelphia: Mosby, Inc.; 2010. p. 177-90.

Huang TT, Liu TC, Chen PR, Tseng FY, Yeh TH, Chen YS. Deep neck infection: analysis of 185 cases. Head \& Neck 2004; 26: 854-60.

Rizzo P, Mosto MCD. Submandibular Space Infection: A Potentially Lethal Infection. International Journal of Infectious Diseases. 2009;13:327-33.

Songu M, Demiray U, Adibelli Z.H, Adibelli H. Bilateral deep neck space infection in the paediatric age group: a case report and review of the literature. ACTA otorhinolaryngologica ita lica. 2010;30:190-193.

Raval CB, Khan MS.Airway management in Submandibular abscess patient with Awake Fibreoptic Intubation. M.E.J. Anesth. 2012 ; 21(4) : 64951.

Stong BC, Johns ME, Johns III MM. Anatomy and Physiology of the Salivary Glands. In : Bailey BJ, Johnson JT, Newlands SD, editors. Head and Neck Surgery Otolaryngology. $\quad 4^{\text {th }} \quad$ ed. Philadelphia: Lippincott Williams \& Wilkins; 2006. p. 518-25.

Chen A, Otto KJ. Differential Diagnosis of Neck Masses. In: Flint PW, Haughey BH, Lund VJ, Niparko JK, Richardson MA, Robbins KT, et al., editors. Cummings Otolaryngology Head \& Neck Surgery. Philadelphia: Mosby, Inc.; 2010. p. 1636-42.

Fragiskos FD. Odontogenic Infections. In: Fragiskos FD, editor. Oral Surgery. Berlin:Springer-Verlag; 2007. p. 232-4.
Rogers J, McCaffrey TV. Inflammatory Disorders of the Salivary Glands. In: Flint PW, Haughey BH, Lund VJ, Niparko JK, Richardson MA, Robbins KT, et al., editors. Cummings Otolaryngology Head \& Neck Surgery. 5th ed. Philadelphia: Mosby, Inc; 2010. p. 1151-3.

Lee YQ, Kanagalingam J. Bacteriology of deep neck abscesses: a retrospective review of 96 consecutive cases. Singapore Med J 2011; 52(5) : 351-5.

Lawson W, Reino AJ, Westreich RW. Odontogenic Infections. In: Bailey BJ, Johnson JT, Newlands SD, editors. Head \& Neck Surgery Otolaryngology. 4th ed. Philadelphia:Lippincott Williams \& Wilkins; 2006. p. 616-28.

Parhiscar A, Har-El G. Deep Neck Abscess: A Retrospective Review of 210 Cases. Ann Otol Rhinol Laryngol. 2001;110:1051-4.

Mazita A, Hazim MYS, Shiraz MAR, Putra SHAP. Neck abscess: five year retrospective review of hospital university kebangsaan Malaysia experience. Med $\mathbf{J}$ Malaysia 2006;61(2): 151-6.

Basith Y, Thiagarajan B. Neck Space infections A Case series study. Otolaryngology online journal. 2013 ; 3(3): 1-10.

Ariji Y, Gotoh M, Kimura Y, Naitoh K, Kurita $\mathrm{K}$, Natsume $\mathrm{N}$, et al. Ondotogenic infection pathway to the submandibular space: imaging assessment. Int. J. Oral Maxillofac Surg. 2002;31:165-9.

Davoodi P, Soufi LR, Jazaeri M, Langaroodi AJ. Submandibular Abcess due to an Infected Keratocystis Odontoegenic Tumor associated with Simultaneous Occurrence of a Traumatic Bone cyst. The Journal of Contemporary Dental Practice. 2013 ; 14(1): 133136. 
Subedi S, Shrestha B, Pandey S. Unilateral Marginal mandibular nerve paresis: A rare complication of submandibular space infection. Journal of Nepal Dental Association. 2013 ; 13(2) : 134-6.

Bakir S, Gunay A, Tanriverdi H, Gün R, Atilgan S, Palanci $\mathrm{Y}$, et al. The Relationship between High Incidence of Deep Neck Infection and Toothbrushing Frequency. Africa Journal of Microbiology Research. 2012;6(6):1221-6.

Rotaru C, Filipov L, Chirila L, Sandulescu M. The esthetic surgical management of a submandibular fascial space infection of odontogenic origin. BMC Infectious Diseases. 2014 ; 14( 7): 69-72. 